\title{
3.2. Nie marnujmy talentów! Wspieranie uczniów zdolnych w praktyce edukacyjnej
}

DOI: 10.47050/65591838.288-297

Tomasz Knopik

Celem artykułu jest prezentacja idei całościowego wspomagania rozwoju uczniów zdolnych w praktyce szkolnej. Na podstawie modelu GROW (G - grupa, R - równowaga, O - osiągnięcia, W - wsparcie) wskazano kluczowe kierunki działań służące aktualizacji zdolności. Ich wspólnym aspektem jest tworzenie warunków sprzyjających ujawnieniu się, docenieniu i rozwinięciu zdolności oraz uzdolnień u jak największej liczby uczniów. Taka strategia wspomagania osób zdolnych wpisuje się bezpośrednio w ideę edukacji włączającej jako nauczania wysokiej jakości dla wszystkich uczniów.

\section{Słowa kluczowe:}

\section{zdolności}




\subsection{Don't waste talent! \\ Supporting gifted students in educational practice}

DOI: $10.47050 / 65591838.288-297$

Tomasz Knopik

The aim of this article is to present the idea of comprehensive support for the development of gifted students in school practice. Based on the GROW model (acronym in Polish: G - group, R - balance, $\mathrm{O}$ - achievements, W - support), the key directions of actions for updating the abilities were indicated. Their common aspect is to create a context conducive to revealing, appreciating and developing the abilities and talents of many students as possible. Such a strategy of supporting gifted people as directly contributes to the idea of inclusive education as high-quality education for all students.

\section{Keywords:}

abilities

talented student 


\section{Uczeń zdolny i jego zróżnicowane potrzeby - anekumena polskiej edukacji?}

Uczniowie zdolni włączeni są do grupy osób ze specjalnymi potrzebami edukacyjnymi (SPE)', co oznacza, że system oświaty powinien zapewniać im odpowiednie wsparcie - w zakresie zarówno identyfikacji potencjału, jak i jego aktualizacji. Praktyka pokazuje jednak, że większość tego rodzaju uczniów nie otrzymuje właściwej pomocy, z czego około połowa w ogóle nie zostaje zdiagnozowana jako osoby ponadprzeciętne. Prowadzi to do sytuacji, w której szkoła nie pełni funkcji miejsca odkrywania talentów, a czasem wręcz odwrotnie - przyczynia się do ich marnowania. Dochodzi do tego na skutek wielu przyczyn, z których najczęstsze to:

$\rightarrow$ skupianie się przez nauczycieli na realizacji podstawy programowej, która określa minimalny poziom efektów uczenia się, co nie sprzyja tworzeniu wykraczających poza standardy sytuacji dydaktycznych;

$\rightarrow$ funkcjonowanie fałszywego stereotypu, że uczniowie zdolni nie wymagają specjalnego wsparcia ze względu na ich ponadprzeciętny potencjał („zdolny i tak sobie poradzi”);

$\rightarrow$ niedostrzeganie potencjału uczniów ze względu na ich trudne zachowanie (przeszkadzanie podczas lekcji, arogancja, agresja werbalna, czasem fizyczna, nadaktywność - symptomy frustracji poznawczej znudzonego i mającego poczucie niezrozumienia ucznia zdolnego interpretowane są jako działania aspołeczne, niewpisujące się w etykietę "zdolnego i grzecznego");

$\rightarrow$ redukowanie uzdolnień uczniów do zakresu przedmiotów szkolnych (nauczyciele poszukują talentów matematycznych, polonistycznych lub plastycznych, podczas gdy paleta możliwości jest znacznie szersza i obejmuje np. umiejętności graficzne, geometryczne - jako dziedziny matematyki lub ekonomiczne);

$\rightarrow$ koncentrowanie uwagi jedynie na potrzebach poznawczych uczniów zdolnych bez uwzględnienia pozostałych komponentów psychicznych warunkujących rozwój potencjału (m.in. twórczość, zaangażowanie zadaniowe, relacje społeczne). 
Zrozumienie istoty zróżnicowanych potrzeb uczniów zdolnych wymaga odpowiedzi na pytanie o to, kim w ogóle jest uczeń zdolny. Na tej podstawie można wskazać kryteria diagnostyczne, które decydują o nominacji nauczycielskiej (identyfikacji, kto jest zdolny). Sami nauczyciele dysponują ponad dwudziestoma różnymi definicjami zdolności (Knopik 2018), co przekłada się na odmienne strategie i decyzje identyfikacyjne. Na podstawie krytycznej analizy literatury przedmiotu w niniejszym tekście wprowadzę następującą terminologię:

a. uczeń zdolny - osoba z ponadprzeciętnym ogólnym potencjałem poznawczym stanowiącym podstawę rozwiązywania problemów w poszczególnych obszarach; najczęstszym wskaźnikiem zdolności jest iloraz inteligencji (stąd w wypadku inteligencji powyżej przeciętnej - IQ>115 - można mówić o uczniu zdolnym, w wypadku inteligencji powyżej 130 - o wybitnie zdolnym, co dotyczy ok. $2 \%$ populacji);

b. uczeń uzdolniony - osoba wykorzystująca swój ponadprzeciętny ogólny potencjał poznawczy w konkretnej dziedzinie, np. muzyce, literaturze, informatyce (stąd uzdolnienia muzyczne, literackie lub informatyczne);

c. uczeń utalentowany - często określenie to traktowane jest jako ekwiwalent terminu "uczeń uzdolniony", można jednak doprecyzować je przez wskazanie poziomu rozwoju uzdolnień - talent jest rozwinięciem uzdolnień, wiąże się z osiągnięciami, z wymiernymi wskaźnikami (nagrody, publikacje, pasje, oryginalne pomysły itp.);

d. zdolności - w ujęciu komponentowym to wynik interakcji między inteligencją (percepcja, pamięć, uwaga, myślenie, wyobraźnia), twórczością (płynność i oryginalność myślenia, otwartość na zmiany, tolerancja ryzyka poznawczego) a motywacją (zainteresowania, pracowitość, tolerancja porażek); zdolności tworzą się zatem i rozwijają na skutek wzajemnego oddziaływania tych trzech komponentów, a troska o uwzględnienie tego założenia zarówno na etapie ich identyfikacji, jak i stymulowania powinna stanowić podstawę kompetentnego wspierania uczniów zdolnych (por. Renzulli 2003).

Swoistym przełomem w międzynarodowym dyskursie wokół zdolności były publikacje Roberta Sternberga, który podważył wcześniejsze, (według niego zbyt optymistyczne) ustalenia psychologów dotyczące 
roli poziomu inteligencji w osiąganiu sukcesu życiowego. Sternberg, analizując biografie wielu wybitnych ludzi, doszedł do wniosku, że sama inteligencja analityczna nie jest wystarczająca (Sternberg 1996). Powinna być ona wsparta inteligencją twórczą oraz praktyczną. Tylko wtedy, dzięki synergii między tymi trzema typami zdolności możliwe jest skuteczne rozwiązywanie problemów z obszaru tzw. pragmatyki życiowej, opracowywanie nowych, niestandardowych strategii działania, a co najbardziej istotne - czerpanie satysfakcji z własnego życia. Sternberg zwrócił zatem uwagę na właściwą funkcję inteligencji, czyli optymalne przystosowanie służące szczęściu człowieka. Wyższa inteligencja zatem powinna wiązać się z lepszą adaptacją, a co za tym idzie - z większym dobrostanem. Niestety, w rzeczywistości zbyt często ponadprzeciętny potencjał związany jest z problemami emocjonalnymi, dystymią, a nawet depresją, zaburzeniami psychicznymi oraz dojmującym poczuciem osamotnienia (Sękowski 2001). Może to oznaczać, że osoba zdolna nie otrzymała odpowiedniego wsparcia $w$ procesie aktualizacji własnego potencjału, a same zdolności, zamiast być katalizatorem rozwoju, pełniły funkcję balastu.

\section{Model wspomagania rozwoju uczniów zdolnych - GROW}

Odwołując się bogatej literatury na temat strategii aktualizacji potencjału uczniów zdolnych (Sękowski 2001; Limont 2011; Pfeiffer i in. 2018) warto wyróżnić cztery kluczowe obszary wsparcia GROW: $\mathrm{G}$ - grupa, $\mathrm{R}$ - równowaga, O - osiągnięcia, W-wsparcie (rys. 1).

Pierwszy z nich wskazuje na konieczność zorganizowania dla uczniów zdolnych grupy odniesienia, stanowiącej optymalną przestrzeń rozwoju zarówno poznawczego, jak i emocjonalno-społecznego. Pojedynczy uczniowie zdolni w klasie muszą bardzo często zmierzyć się z dylematem: pozostać sobą czy "na siłę" upodobnić się do innych. Oryginalność, przejawiająca się m.in. specyficznym poczuciem humoru, specjalistycznymi zainteresowaniami czy nasiloną ciekawością poznawczą, skazuje ich na indywidualizm, a nawet wyalienowanie. Chcąc przynależeć do grupy, celowo ograniczają swoje niekonwencjonalne zachowania, co hamuje rozwój zarówno ich zdolności, jak i osobowości (rezygnacja podmiotu z kluczowych wartości). Dlatego tak istotnym zadaniem szkoły jest stworzenie każdemu uczniowi zdolnemu odpowiedniego środowiska rówieśniczego, w którym nie będzie musiał wchodzić w rolę kogoś innego, niż naprawdę jest. Ponadto współpraca 
z innymi zdolnymi rówieśnikami stymuluje ich wszechstronny rozwój, dając szansę na osiągnięcie synergii i poradzenie sobie z wyzwaniami, z którymi pojedynczy umysł nie miałaby szans się zmierzyć. Wspólne (a nie osamotnione - jak najczęściej bywa w rzeczywistości szkolnej) rozwiązywanie problemów to jedna z najbardziej efektywnych strategii aktualizacji potencjału uczniów ponadprzeciętnych (Knopik 2018).

Rysunek 1. Model GROW - cztery kluczowe obszary wspierania ucznia zdolnego

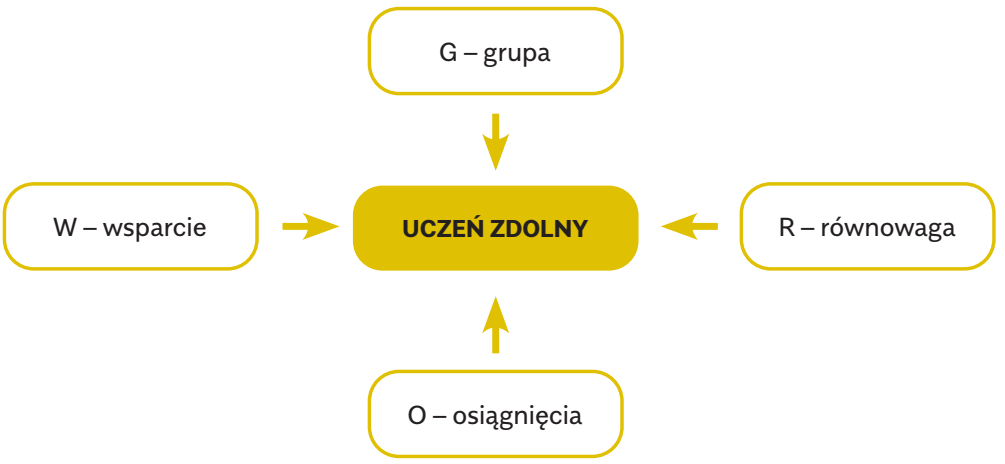

Źródło: Opracowanie własne.

Równowaga wskazuje na konieczność wspierania nie tylko rozwoju poznawczego uczniów zdolnych, ale także pozostałych sfer (osobowość, obszar emocjonalno-motywacyjny, relacje społeczne, sprawność ruchowa, orientacja aksjologiczna, kreatywność), równie istotnych dla wykorzystania posiadanego potencjału w procesie optymalnej adaptacji życiowej. Zdecydowana większość działań rodziców i nauczycieli skupia się na poszerzaniu wiedzy swoich uzdolnionych dzieci, co - jak wskazuje praktyka - nie wystarcza do osiągnięcia sukcesu (określonego przez Sternberga $w$ jednej z teorii inteligencji jako "powodzenie życiowe”). Brak równowagi wynikający ze zbyt wczesnej i zbyt intensywnej stymulacji poznawczej dzieci może również przejawiać się w ich asynchronii rozwojowej, manifestującej się m.in. niestabilnością i nadwrażliwością emocjonalną (asynchronia w aspekcie afektywnym), niezbornością ruchową (asynchronia w aspekcie motorycznym) czy osamotnieniem (asynchronia w aspekcie społecznym). 
Trzecim obszarem są osiągnięcia, stanowiące ważną informację dla uczniów zdolnych w procesie budowania obrazu siebie, a więc samowiedzy i samooceny. Sukcesy i porażki pozwalają określić im mocne oraz słabe strony, a na tej podstawie adekwatnie skonstruować ścieżkę własnego rozwoju (co jest szczególnie ważne, biorąc pod uwagę zjawisko posiadania przez uczniów zdolnych wielu zainteresowań). Osiągnięcia pełnią istotną funkcję w budowaniu trwałej motywacji do rozwijania swoich zdolności - powinny one jednak być rozpatrywane w perspektywie zarówno nagród zewnętrznych (np. laury w konkursach, olimpiadach), jak i wewnętrznych gratyfikacji (transgresje - przekraczanie własnych granic) (por. Kozielecki 2007).

Ostatni obszar - wsparcie - dotyczy czynników środowiskowych niezbędnych do rozwijania uzdolnień uczniów. Można wśród nich wymienić zasoby:

$\rightarrow$ ludzkie (dostęp do ekspertów z danej dziedziny, wsparcie psychologiczne, pomoc ze strony nauczycieli, rodziców);

$\rightarrow$ materialne (profesjonalny sprzęt, specjalistyczne oprogramowanie, instrumenty muzyczne, dostęp do dobrze wyposażonych bibliotek);

$\rightarrow$ organizacyjne (realizacja przez szkoły systemowych rozwiązań w zakresie wspierania zdolności, kultura uczenia się danej szkoły sprzyjająca rozwojowi uczniów zdolnych, dostęp do organizacji specjalizujących się w udzielaniu pomocy grupie uczniów ze specjalnymi potrzebami edukacyjnymi, regionalne programy wsparcia).

Wymienione obszary nie wyczerpują wszystkich potrzeb uczniów zdolnych - wskazują jednak główne kierunki działań pomocowych, ułatwiających tworzenie przez szkoły własnych programów wspomagania rozwoju talentów z wykorzystaniem lokalnych zasobów i po uwzględnieniu specyfiki danego środowiska (np. poziom współpracy z rodzicami, popularność inicjatyw międzyszkolnych, otwartość na zmiany).

\section{Dobre praktyki - GROW w dzialaniu}

W tabelach poniżej zamieszczono przykładowe rozwiązania realizujące kierunki wsparcia opisane w modelu GROW. Należy pamiętać, że o efektywności udzielanej pomocy decyduje jej całościowy charakter, stąd tak ważne jest uwzględnienie w projektowanych działaniach wszystkich czterech obszarów. 


\section{Obszar: GRUPA}

\begin{tabular}{l|l}
\multicolumn{1}{c|}{ TYP DZIAtANIA } & \multicolumn{1}{c}{ opIS DzıAtANIA } \\
\hline $\begin{array}{l}\text { Międzyklasowe } \\
\text { lub międzyszkolne } \\
\text { koła zainteresowań }\end{array}$ & $\begin{array}{l}\text { Działania te pozwalają wyodrębnić grupy uczniów na podobnym poziomie uzdol- } \\
\text { nień, co umożliwiłoby ich wzajemną stymulację. Często koła zainteresowań } \\
\text { dla danej klasy nie pełnią rozwijającej i integrującej funkcji ze względu na ponow- } \\
\text { ne osamotnienie ucznia zdolnego (podobnie jak podczas zajęć programowych). }\end{array}$ \\
\hline Obozy naukowe & $\begin{array}{l}\text { Interdyscyplinarne kilkudniowe spotkania są okazją do dzielenia się z innymi } \\
\text { uczniami zdolnymi swoimi obecnymi zainteresowanymi i osiągnięciami, } \\
\text { np. w ramach badania danego zjawiska przyrodniczego. Ponadto, obozy rozwijają } \\
\text { kompetencje społeczne, pozwalają uczestnikom przewartościować swoje do- } \\
\text { tychczasowe myślenie o sobie (np. postrzeganie siebie jako dziwaka) i z zupełnie } \\
\text { innym nastawieniem powrócić do szkoły. }\end{array}$ \\
\hline $\begin{array}{l}\text { Zespoły zadaniowe } \\
\text { (projektowe) }\end{array}$ & $\begin{array}{l}\text { Mogą powstawać w ramach jednej klasy, szkoły lub sieci szkół np. w danym } \\
\text { mieście. Członkowie grupy, zgodnie z ideą projektu, sami formułują interesujące } \\
\text { ich problemy badawcze i opracowują strategię poszukiwania na nie odpowiedzi. } \\
\text { Ważnym wsparciem dla zespołów zadaniowych są eksperci - nauczyciele } \\
\text { lub osoby z zewnętrz (np. naukowcy, pracownicy przedsiębiorstw). }\end{array}$
\end{tabular}

\section{Obszar: RÓWNOWAGA}

TYP DZIAKANIA

Zachęcanie uczniów zdolnych do aktywności fizycznej

\section{OPIS DZIAŁANIA}

Uczniowie zdolni często unikają zajęć sportowych, dlatego że preferują te aktywności, w których mogą być co najmniej dobrzy (w konfrontacji z rówieśnikami). Stąd ważna jest zachęta do podejmowania tego typu działań przez umiejętne łączenie ćwiczeń fizycznych z wysiłkiem poznawczym. Na przykład: Matematyczna Liga Futbolowa (dostęp do dodatkowych rzutów karnych warunkowany jest poprawnym rozwiązaniem zadania przez drużynę lub pojedynczego zawodnika, gol premiowany dodatkowym punktem, możliwość anulowania gola pod warunkiem podania rozwiązania zagadki matematycznej), maraton historyczny (bieg z zagadkami historycznymi - warunkiem zaliczenia całej trasy jest znalezienie rozmieszczonych w różnych punktach zagadek oraz ich rozwiązanie). Warto dodać, że tego typu ćwiczenia motywują również do aktywności poznawczej tych uczniów, którzy zazwyczaj lepiej radzą sobie z wysiłkiem fizycznym.

Edukacja ku mądrości
Ten typ działań związany jest z kształtowaniem u uczniów zdolnych orientacji prospołecznej, ukierunkowanej na troszczenie się o wspólne dobro. Dzięki rozwijaniu trzech typów myślenia - refleksyjnego, dialektycznego i dialogicznego - poszerzają oni perspektywę postrzegania świata i ujmowania problemów w taki sposób, że dostrzegają ich wieloaspektowość oraz zróżnicowanie znaczeń (w percepcji zaangażowanych w nie podmiotów). W tym sensie edukacja ku mądrości kształtuje empatię uczniów zdolnych i chroni ich przed megalomanią, egocentryzmem czy nadmiernym krytycyzmem (Knopik 2018). 
Rozwój emocjonalno-społeczny
Wysokie ryzyko asynchronii rozwojowej uczniów zdolnych wymaga spójnych działań w obszarze kształtowania ich kompetencji emocjonalno-społecznych. Włączenie tych czynności w realizację podstawy programowej (zamiast tworzenia specjalnych zajęć temu poświęconych) daje szansę na wyposażenie uczniów w trwałe zasoby transferowalne, umożliwiające im obecną i przyszłą adaptację.

Sposoby rozwijania kompetencji emocjonalno-społecznych w ramach realizacji podstawy programowej zostały zawarte w cyklu poradników w pakiecie TROS-KA (Domagała-Zyśk i in. 2017).

\section{Obszar: OSIĄGNIĘCIA}

\section{TYP DZIAŁANIA}

Udział w konkursach, Tego rodzaju działania sprawdzają efektywność udzielanego wsparcia, szczególolimpiadach nie w aspekcie poznawczym. Nie należy jednak traktować ich jako bezpośredniej i najważniejszej pomocy kierowanej do uczniów zdolnych. Warto pamiętać, że angażowanie tej samej osoby do kilku olimpiad może prowadzić do przeciążenia poznawczego i emocjonalnego, a także zredukowania roli ucznia do zawodnika biorącego udział w kolejnych konkursach.

Indywidualne plany rozwoju

Wspólne opracowanie z uczniem zdolnym jego indywidualnej ścieżki rozwoju, z wyraźnie opisanymi celami do osiągnięcia na poszczególnych etapach jest najlepszą strategią wzmacniania jego poczucia kompetencji i włączania ewentualnych gratyfikacji zewnętrznych w jego system wartości. W planach dostosowanych do osobistego potencjału uczeń może zaobserwować pokonywanie kolejnych granic (transgresje), co przekłada się na wzrost jego motywacji wewnętrznej - jednego z trzech kluczowych komponentów zdolności.

Organizacja konkursów dostosowanych do specyficznych uzdolnień uczniów
Uczniowie o bardzo specjalistycznych uzdolnieniach i zainteresowaniach, niekoniecznie pokrywających się z zakresem przedmiotów szkolnych, nie mają okazji do zaprezentowania swoich możliwości na zewnątrz (choć wykazują taką potrzebę). Stąd cenne są wszelkie inicjatywy organizacji wydarzeń wychodzących poza dotychczasowe praktyki, np. konkursy z zakresu historii polskiego futbolu lub projektowania architektury miejskiej, wystawa memów medycznych.

\section{Obszar: WSPARCIE}

TYP DZIAŁANIA

Współpraca szkół z podmiotami zewnętrznymi

\section{OPIS DZIAŁANIA}

Podejmowanie wspólnych inicjatyw z ekspertami z uczelni, lokalnych ośrodków kultury, organizacji pozarządowych w zakresie organizacji specjalistycznych zajęć rozwijających uzdolnienia. Uczelnie w ramach tzw. trzeciej misji są zobligowane do angażowania się w działania na rzecz środowiska lokalnego i wspomagania wszystkich potencjalnie zainteresowanych osób w procesie zdobywania zweryfikowanej metodami naukowymi wiedzy o współczesnym świecie.

Aktualizacja wiedzy nauczycieli na Pedagog lub psycholog szkolny powinni na bieżąco monitorować inicjatywy mające na celu wspomaganie uczniów zdolnych. Okazuje się, że częstą barierą udziału w tych przedsięwzięciach jest brak dostępu do informacji. Tego typu oferty powinny być również dostępne dla rodziców, którzy w ramach czasu wolnego chcieliby wspomóc rozwój swoich dzieci. temat regionalnych i ogólnopolskich programów wspierania uczniów zdolnych 


\begin{tabular}{l|l}
\hline $\begin{array}{l}\text { Szkolenia z zakresu } \\
\text { pracy z uczniami }\end{array}$ & $\begin{array}{l}\text { Stworzenie atmosfery rzeczywiście sprzyjającej rozwojowi uczniów zdolnych } \\
\text { zdolnymi }\end{array}$ \\
trzebaga poznania specyfiki ich funkcjonowania oraz strategii zaspokajania ich po- \\
tradry pedagogicznej daje szansę na systemowe (a nie wybiórcze) podejście do \\
tematu rozwijania talentów, dzięki czemu działania podejmowane przez poszcze- \\
gólnych nauczycieli będą spójne, co znacznie podniesie ich efektywność.
\end{tabular}

\section{Podsumowanie}

Edukacja włączająca ma na celu stworzenie optymalnych warunków uczenia się dla wszystkich uczniów. I choć największa uwaga skupiona jest na zaprojektowaniu odpowiedniego wsparcia osób z niepełnosprawnościami i innymi trudnościami (barierami) rozwojowymi, nie można pomijać uczniów zdolnych. Stanowią oni 16-20\% populacji wszystkich uczniów, co oznacza, że należy w nowym modelu edukacji włączającej zadbać o ich potrzeby. Walcząc z różnymi odmianami dyskryminacji w polskiej szkole, nie zapominajmy o wyzwaniu, jakim jest dyskryminacja ze względu na zdolności. Do zbioru takich określeń typu ageizm, seksizm czy adultyzm można dodać zjawisko zwane "giftyzmem". Kontynuując tę myśl, warto zatem skonkludować, że jednym z obszarów inkluzji powinniśmy uczynić "antygiftyzm”, nie stać nas bowiem na marnowanie talentów. Co więcej-marnowanie talentów jest moralnie naganne! 